\title{
Growth and phytoremediative capacity of Eleusine indica in a typical farmland soil under previous exposure to organochlorine pesticide
}

\author{
Beckley Ikhajiagbe $^{1}$, O. G. Anoliefo ${ }^{1}$, S. I. Musa ${ }^{2, *}$, E.O. Ohanmu ${ }^{3}$ \\ ${ }^{1}$ University of Benin. ${ }^{2}$ Admiralty University of Nigeria. ${ }^{3}$ Edo University Iyamho. \\ *Corresponding author. @ musa-biology@adun.edu.ng
}

\begin{abstract}
This study investigated the growth and phytoremediative response of Eleusine indica in a typical farmland soil that had been exposed to organochlorine pesticides. Different soil treatments were obtained by mixing pesticide polluted soil $(\mathrm{P})$ with control soil $(\mathrm{C})$ in ratios, 1P:99C, 5P:95C, 50P:50C, 25P:75C, 75P:25C, 100P and 100C. Three-leaf tillers of the test plant were sown in all the treatments for 3 months. The results revealed that there were no significant differences in all plant morphological parameters measured between plants in $\mathrm{P}$ impacted soils and $\mathrm{C}$-soil. All the $\mathrm{pH}$ values were acidic, although an increase in $\mathrm{pH}$ and decrease in conductivity was observed with the introduction of the test plant. There was reduction in total pesticide residual (TPR) contents in the soil as a result of the plant activities. Significant reduction in $\mathrm{q}-\mathrm{BHC}, \alpha-$ chlordane and $\Upsilon-$ chlordane was observed in the P1:C99 soil mix; a 90\% remediation efficiency $\left(1.663 \mathrm{mg} \mathrm{kg}^{-1}\right)$ was registered in the all treatments. This study thus presents $E$. indica as a potential concentrationdependent phytoremediator of pesticide, with no significant morphological changes.
\end{abstract}

Keywords: Eleusine indica, organochlorine Persistent organic compound.

\section{Introduction}

The pesticide industry is a major cause of environmental pollution globally, particularly in agricultural production systems. Pesticides, especially the Persistent Organic Pollutants (POPs) are inert and have been documented to leave residues in soils. They are widely studied due to their persistence, high toxicity, low biodegradability, and bio solubility in fat tissue (UNEP, 2007). The persistence and toxic nature of these pesticides has posed a serious environmental and human health risks resulting from pesticides residues discoverable in agricultural products grown using such chemicals (Olawale et al., 2011). Agricultural crops have also been reported to accumulate these pesticides and relay them into food chains and water bodies (Obida et al., 2012), which may likely cause harm to non-target organisms and thereby affect food security. Pesticides have also threatened the survival of less tolerance plant and animal species (Helfrich et al., 2009) causing necrosis and chlorosis of leaf structures (Musa et al., 2019) and human health complications (Lah, 2011). 
A number of POPs such as organochlorine pesticides (OCPs) are used to control crop pests abd disease causing human pests (Lal and Saxena, 1982; UNEP, 2003; Arslan et al. 2015). As a result of chlorines" affinity for dispersal, transportation over long distances, bioaccumulation in the food chain and long half-life, organochlorine pesticides have been considered of great risk to the global environment and may compromise human health (Laws, 2000). They are majorly five groups of such compounds these include: Dichlorodiphenyltrichloroethane (DDT) and its analogues e.g., the Hexachlorocyclohexane $(\mathrm{HCH})$ and its isomers $\alpha-\mathrm{HCH}, \beta-\mathrm{HCH}, \gamma-$ $\mathrm{HCH}$, and $\delta-\mathrm{HCH}$; the Cyclodienes e.g., endosulfan, aldrin, endrin, dieldrin, chlordane, the Chlordecones, Murex, Kelevan and the Toxaphenes (Pope et al., 1994). Its release and persistence in the environment make it to bioaccumulate and biomagnified in the body fat, liver and other organs resulting in serious complications and even death (Dewailly et al. 1999). Similarly, the presence of pesticides and pesticide residues in soils can cause abiotic stress symptoms in plants, such as changes in amino acid, carbohydrates and amine metabolic pathways. These changes are in most cases manifested morphologically through symptoms such as necrosis, chlorosis and low plant yield. Such responses may vary and this phenomenon may be important in selecting pesticide stress-tolerant plants (Barrett, 1998). Anoliefo et al. (2006, 2008) suggested that the abundance of a particular plant in a contaminated area indicates that such a plant may show tolerance to that particular contaminant, and therefore may be a likely candidate for phytoremediation of that contaminant. Phytoremediation is the biotechnological use of organisms such as plants, animal or microorganisms to take up or breakdown contaminants from the environment (McCutcheon and Schnoor 2003; Yanyu et al., 2010; Khan et al., 2014). Previous studies by Sandra et al. (2015) have evaluated the effectiveness of Ricinus communis to reduce organochlorine pesticides residues in previously exposed soils. Some studies have also shown the use of crops and wetland plants synergistic role with bacteria in the uptake and transformation of contaminants (Abhilash et al., 2011; Becerra-Castro et al., 2013; Miguel et al., 2013).

This study aimed to as investigate growth and phytoremediative efficacy of Eleusine indica in farmland soil initially exposed to organochlorine pesticides. E. indica is regarded as an environmental tolerant plant and can withstand most biotic and abiotic stress, this justified the choice of using it as test plant. Also, the plant has been discussed by previous studies to have capabilities for remediation of hydrocarbon-polluted soils (Anoliefo et al., 2006; Anoliefo et al., 2008; Ikhajiagbe and Anoliefo, 2012). This research thus proposed to test its response to organochlorine. The objective of this study was to investigate growth and phytoremediative response of Eleusine indica in a typical farmland soil, previously exposed to organochlorine pesticides.

\section{Materials and Methods}

\section{Study Area}

A farmland, owned and managed collectively by peasant farmers, located near Ukhun village, en route Ekpoma, Edo State in Nigeria, with history of long-term organochlorine pesticide usage (Ikhajiagbe et al., 2016), was selected for the study (Figure 1). Top soil $(0-10 \mathrm{~cm}$ ) was obtained randomly from within a marked out $50 \mathrm{~m}$ x $50 \mathrm{~m}$ plot within the farm, and transported in polybags to the Screen house at the Department of Plant Biology and Biotechnology, University of Benin, Nigeria, for study. 


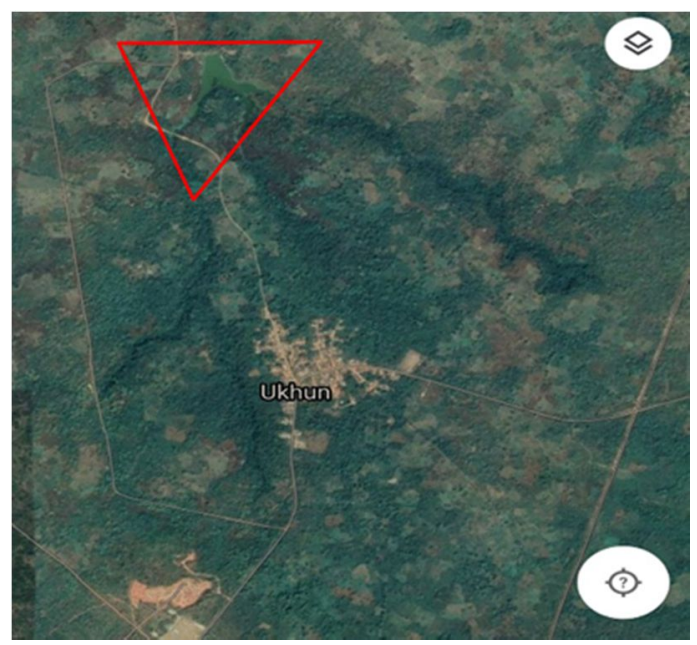

Figure 1. Study Area.

\section{Collection and Processing of Materials}

The organochlorine pesticide polluted farmland soils $(\mathrm{P})$ were sun-dried to constant weight 10 $\mathrm{kg}$ each were put in wide experimental bowls with no perforations made at the bottom. This was deliberate so as not to lose the pesticide residues to drainage and downward infiltration. The soil was prepared in 7 treatments based on polluted soil-control soil mix. Control soil (C) was collected from the Departmental Botanic Garden, where pesticides had not been used more than 20 years based on information provided by the Chief Laboratory Technologist. Soil was mixed in the following ratios 1P:99C, 5P:95C, 50P:50C, 25P:75C and 75P:25C. 100P as well as $100 \mathrm{C}$ were used as both negative controls and positive controls, respectively. These treatments were made in 3 replicates in a completely randomized block design. The set was immediately sown with 4-leaf tillers of Eleusine indica that were originally raised in a control nursery soil. The nursery soil used as the control was a humus soil obtained at the Botanic Garden of two weeks old. The general characteristics of the tillers used is presented in Table 1 .

The experiment was observed at the postgraduate research farm for 3 months with regular wetting to maintain adequate soil moisture content, relying on the Soil Moisture Feel Test proposed by USDA (1998).

\section{Plant Analysis}

Plant morphological parameters considered in this study were plant height, flag leave blade length, peduncle length, number of leaves, total number of primary roots branches, length of main root, number of tillers per plant, number of spikes per plant and length of longest spike were as proposed by Ikhajiagbe et al. (2019) using a transparent meter rule and counting.

\section{Soil Sampling and Analysis}

Soil samples were taken before establishing the study to assess baseline conditions; and during the study at 3 months to assess changes in residual pesticide residue concentrations. Soil $\mathrm{pH}$ was determined using the glass electrode procedure. Measurement was done using a $\mathrm{pH}$ meter (Hanna Model). Soil conductivity was determined using conductivity meter (Hanna Model) and 
soil temperature was obtained by using thermometer. Levels of organochlorine pesticide usage was therefore necessary for analysis of organochlorine pesticide residues in the soil before and after the test plant has been introduced. These were assessed using standard methods following ASTM D6160 - 98 (2013).

\section{Data Analysis}

Data obtained were presented in means and standard errors of three replicates. Data were analyzed following two-way analysis of variance using GENSTAT (8th edition). Where significant p-values were obtained, differences between means were separated using Student Newman Keuls test following (Ogbeibu, 2005).

\section{Results and Discussions}

\section{Morphology of Eleusine indica Tillers}

The average morphological parameters of tillers before transplanting (nursery stage) is presented in Table 1. Plants used for this study were within a height of $13.1 \pm 5.2 \mathrm{~cm}$ before exposure. After exposure to different organochlorine pesticide polluted-soil mixtures, results showed no significant differences $(\mathrm{p}>0.05)$ in all morphological parameters of E. indica plants

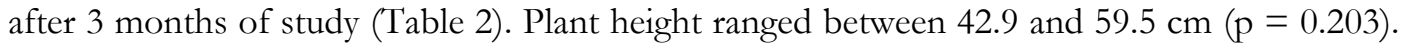
Likewise, plants exposed to organochlorine pesticide polluted-soil treatments showed no significant differences in peduncle length $(5.3-7.4 \mathrm{~cm} ; \mathrm{p}=0.632)$. Similarly, no significant changes in root parameters were registered $(\mathrm{p}>0.05)$. From this, it is clear that organochlorine pesticide has no effect on the morphology of E. indica and therefore, the crop can tolerate pesticide stress. For a plant to be tested for phytoremediation, it must exhibit the ability to tolerate the chemical (Sarvajeet et al., 2016). Results from this study are in line with those reported by Ikhajiagbe and Anoliefo (2012), who suggested E. indica as a potential species for remediation of hydrocarbon pollution. However, the absence of significant changes in plant morphology even when exposed to organochlorine pesticide polluted soil disagrees with work presented by Ikhajiagbe et al., 2016 and Musa et al., 2019 who worked with phosphate pesticide and heavy metals respectively.

Table 1. Morphological parameters of Eleusine indica tillers before transplanting.

\begin{tabular}{ll}
\hline Plant parameter & Value \\
\hline Plant Height $(\mathrm{cm})$ & $13.1 \pm 5.2$ \\
Flag leave blade length $(\mathrm{cm})$ & $12.6 \pm 5.1$ \\
Peduncle length & 0 \\
No of leaves & $6 \pm 2$ \\
Total No of primary root branches & $7 \pm 3$ \\
Length of main root & $11.3 \pm 4.6$ \\
No. of tillers per plant & 1 \\
No of spike/plant & 0 \\
Length of longest spike $(\mathrm{cm})$ & 0 \\
\hline
\end{tabular}


Table 2. Morphological parameters of Eleusine indica plants exposed to pesticide-polluted soils at 3 months.

\begin{tabular}{|c|c|c|c|c|c|c|c|c|}
\hline & $100 \mathrm{C}$ & 1P:99C & $5 \mathrm{P}: 95 \mathrm{C}$ & $50 \mathrm{P}: 50 \mathrm{C}$ & $25 \mathrm{P}: 75 \mathrm{C}$ & $75 \mathrm{P}: 25 \mathrm{C}$ & $100 \mathrm{P}$ & p-value \\
\hline Plant 1 & $59.5^{\mathrm{a}}$ & $49.3^{\mathrm{a}}$ & $48.2^{\mathrm{a}}$ & $42.9^{a}$ & $51.4^{\mathrm{a}}$ & $48.4^{\mathrm{a}}$ & $51.5^{\mathrm{a}}$ & 0.203 \\
\hline Flag leave blade length (cm) & $27.5^{\mathrm{a}}$ & $18.4^{\mathrm{ab}}$ & $16.4^{\mathrm{b}}$ & $22.5^{\mathrm{a}}$ & $18.5^{\mathrm{ab}}$ & $21.5^{\mathrm{a}}$ & $20.6^{\mathrm{ab}}$ & b 0.249 \\
\hline Peduncle length & $6.8^{\mathrm{b}}$ & $5.3^{\mathrm{b}}$ & $6.7^{\mathrm{b}}$ & $7.4^{\mathrm{b}}$ & $6.2^{\mathrm{b}}$ & $6.6^{\mathrm{b}}$ & $5.9^{\mathrm{b}}$ & 0.632 \\
\hline No o & $54^{\mathrm{b}}$ & $45^{\mathrm{ab}}$ & $53^{\mathrm{a}}$ & $49^{\mathrm{ab}}$ & $51^{\mathrm{a}}$ & $41^{\mathrm{b}}$ & $48^{\mathrm{ab}}$ & 0.391 \\
\hline No. & $9^{\mathrm{a}}$ & $7^{\mathrm{a}}$ & $8^{\mathrm{a}}$ & $6^{\mathrm{a}}$ & $6^{\mathrm{a}}$ & $8^{\mathrm{a}}$ & $7^{\mathrm{a}}$ & 0.258 \\
\hline No & $21^{\mathrm{a}}$ & $16^{\mathrm{ab}}$ & $18^{\mathrm{ab}}$ & $14^{\mathrm{b}}$ & $18^{\mathrm{ab}}$ & $19^{\mathrm{ab}}$ & $19^{\mathrm{ab}}$ & 0.428 \\
\hline Leng & $4.3^{\mathrm{a}}$ & $4.2^{\mathrm{a}}$ & $4.2^{\mathrm{a}}$ & $3.8^{\mathrm{a}}$ & $4.3^{\mathrm{a}}$ & $4.6^{\mathrm{a}}$ & $4.3^{\mathrm{a}}$ & 0.582 \\
\hline $\begin{array}{l}\text { Total number of primary root } \\
\text { branches }\end{array}$ & $32^{\mathrm{a}}$ & $24^{\mathrm{a}}$ & $21^{\mathrm{a}}$ & $28^{\mathrm{a}}$ & $27^{\mathrm{a}}$ & $21^{\mathrm{a}}$ & $29^{\mathrm{a}}$ & 0.639 \\
\hline Length of main root & $48.6^{\mathrm{a}}$ & $46.8^{\mathrm{a}}$ & $53.2^{\mathrm{a}}$ & $49.6^{\mathrm{a}}$ & $47.9^{\mathrm{a}}$ & $52.0^{\mathrm{a}}$ & $53.4^{\mathrm{a}}$ & 0.513 \\
\hline
\end{tabular}

*Means with similar alphabetic superscripts on the same row do not differ from each other ( $\mathrm{p}>0.05)$. P polluted farm soil; $\mathrm{C}$ control soil.

\section{Pesticide Residual Concentrations}

After 3 months of study, changes in pesticide residues in the soil sown with Eleusine indica plants were evaluated against baseline values (Table 3, Figure 3a-f). There was significant reductions in Aldrin concentrations from 0.099 to $0.004 \mathrm{mg} \mathrm{kg}^{-1}$ and total removal of d-BCH, q-BCH and decachlorobiphenyl by Eleusine indica across the treatments. This may be as a result of phytoaccumulation, phytotransformation and rhizoremediation which are the strategies plants use in the uptake of organochlorine pesticide (Tanvi and Dileep, 2017). The 100P soil mixture had the highest total pesticide residual content, while the 1P:99C recorded least or no pesticide residual content. The high total pesticide residual content observed in the $100 \mathrm{P}$ mixture may have been caused by the high POPs found in the 100P treatment affected the phytoremediative strength of the test plant. On the other hand, the low pesticide residual content observed in the 1P:99C treatment could indicate that Eleusine indica showed perfect premeditative activity ( $>90 \%$ remediation efficiency) in soil with the lowest concentration of pesticide (1P:99C). This implies that the performance of the test plant as a phytoremediator may have been concentration-dependent.

The organochlorine pesticides are taken up by plant by penetrating the roots through simple diffusion by the cell wall; and then subsequently translocated through xylem to other parts (Schroll et al., 1994; Trapp and Matthies 1997). Furthermore, differences in the removal and uptake of the pesticide contents were observed across the treatments. This may be attributed to the roots of the test plant in agreement with a study be Agbeve et al. (2013) suggesting that organochlorine pesticide contents such as $\beta-\mathrm{HCH}, \gamma-\mathrm{HCH}, \delta-\mathrm{HCH}$, aldrin, heptachlor, $\alpha-$ endosulfan, $\beta$-endosulfan, $\gamma$-chlordane, dieldrin and endrin have been determined in the root tissues of Cryptolepis sanguinolenta.

Figure 2 shows the correspondence analyses showing relationship between treatments and pesticide composition of soil samples. The result showed that majority of the pesticide were associated with T6 (the 100\% polluted farm soil), including $\alpha$ - chlordane, $\Upsilon$ - chlordane, p, p DDD, p, p DDE, endosulfan II and Heptachlor. 
Table 3. Pesticide residual composition of soils sown with Eleusine indica plants after 3 months.

\begin{tabular}{|c|c|c|c|c|c|c|c|c|}
\hline & $\begin{array}{l}\text { Baseline, } \\
\text { NF }\end{array}$ & $100 \mathrm{C}$ & 1P:99C & $5 \mathrm{P}: 95 \mathrm{C}$ & $50 \mathrm{P}: 50 \mathrm{C}$ & $25 \mathrm{P}: 75 \mathrm{C}$ & $75 \mathrm{P}: 25 \mathrm{C}$ & $100 \mathrm{P}$ \\
\hline Aldrin & 0.099 & 0.004 & 0.006 & 0.009 & 0.01 & 0.017 & 0.013 & 0.004 \\
\hline $\mathrm{a}-\mathrm{BHC}$ & 0.029 & 0.003 & 0.002 & 0.004 & 0.003 & 0.003 & 0.005 & 0.011 \\
\hline $\mathrm{b}-\mathrm{BHC}$ & 0.216 & 0.011 & 0.002 & 0.002 & 0 & 0 & 0 & 0.003 \\
\hline $\mathrm{d}-\mathrm{BHC}$ & 0.016 & 0 & 0.004 & 0.005 & 0 & 0.004 & 0.006 & 0.01 \\
\hline$q-B H C$ & 0.008 & 0 & 0 & 0.008 & 0.009 & 0.007 & 0.021 & 0.017 \\
\hline$\alpha-$ chlordane & 0.014 & 0.012 & 0 & 0 & 0.006 & 0.01 & 0.004 & 0.01 \\
\hline$\Upsilon$ - chlordane & 0.036 & 0.007 & 0 & 0 & 0 & 0 & 0 & 0.018 \\
\hline $\mathrm{p}, \mathrm{p}$ DDD & 0.049 & 0.017 & 0 & 0 & 0 & 0 & 0 & 0.071 \\
\hline $\mathrm{p}, \mathrm{p}$ DDE & 0.101 & 0 & 0 & 0 & 0.013 & 0 & 0.007 & 0.048 \\
\hline $\mathrm{p}, \mathrm{p}$ DDT & 0.296 & 0 & 0 & 0 & 0 & 0.011 & 0 & 0.011 \\
\hline Dieldrin & 0.061 & 0 & 0 & 0 & 0 & 0 & 0 & 0.039 \\
\hline endosulfan I & 0.052 & 0.012 & 0.01 & 0.009 & 0.017 & 0 & 0 & 0.024 \\
\hline endosulfan II & 0.039 & 0 & 0 & 0 & 0.006 & 0.017 & 0.013 & 0.074 \\
\hline endosulfan sulfate & 0.216 & 0.011 & 0.004 & 0.005 & 0.009 & 0.004 & 0.006 & 0.016 \\
\hline Endrin & 0.021 & 0.005 & 0.01 & 0.005 & 0.007 & 0.009 & 0.006 & 0.044 \\
\hline endrin aldehyde & 0.039 & 0.008 & 0 & 0.004 & 0.009 & 0.009 & 0.007 & 0.017 \\
\hline Heptachlor & 0.040 & 0.005 & 0.006 & 0.007 & 0.011 & 0.007 & 0.011 & 0.037 \\
\hline heptachlor epoxide & 0.009 & 0.008 & 0.006 & 0.007 & 0.008 & 0.006 & 0.008 & 0.012 \\
\hline Methoxychlor & 0.072 & 0.008 & 0.007 & 0.008 & 0.014 & 0.01 & 0.011 & 0.067 \\
\hline TCMX & 0.006 & 0.007 & 0.005 & 0.007 & 0.024 & 0.195 & 0.022 & 0.005 \\
\hline decachlorobiphenyl & 0.307 & 0.008 & 0 & 0 & 0.011 & 0.177 & 0.011 & 0 \\
\hline Total (mg/kg) & 1.726 & 0.128 & 0.063 & 0.079 & 0.157 & 0.485 & 0.151 & 0.570 \\
\hline
\end{tabular}

*P polluted farm soil; C control soil

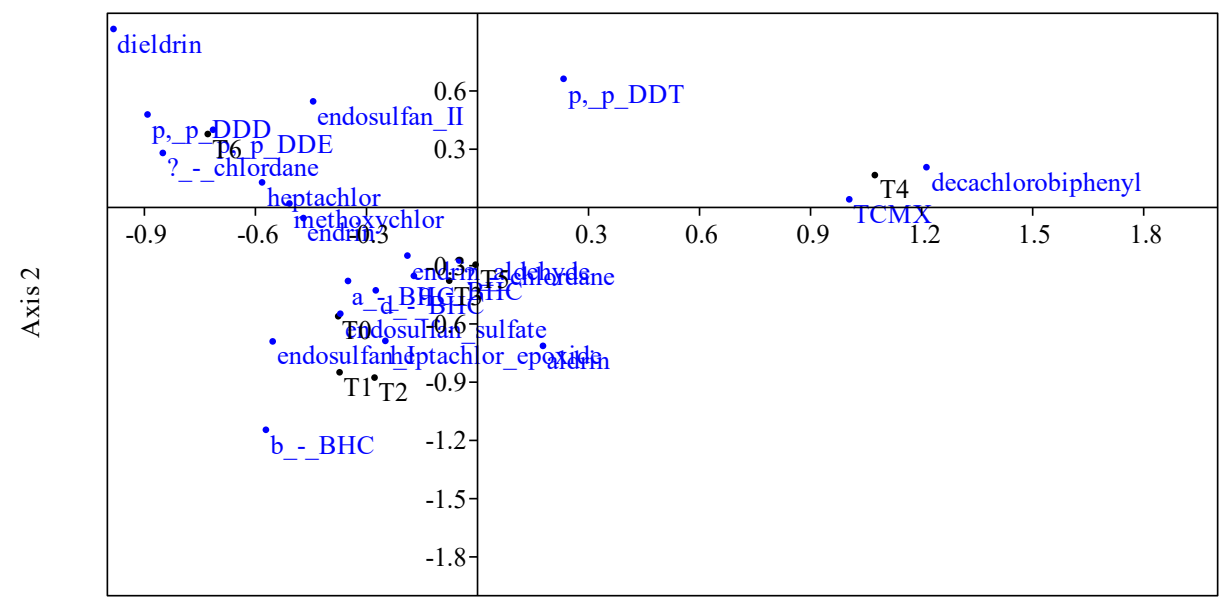

Axis 1

Figure 2. Correspondence analyses showing relationship between treatments and pesticide composition of soil samples. 


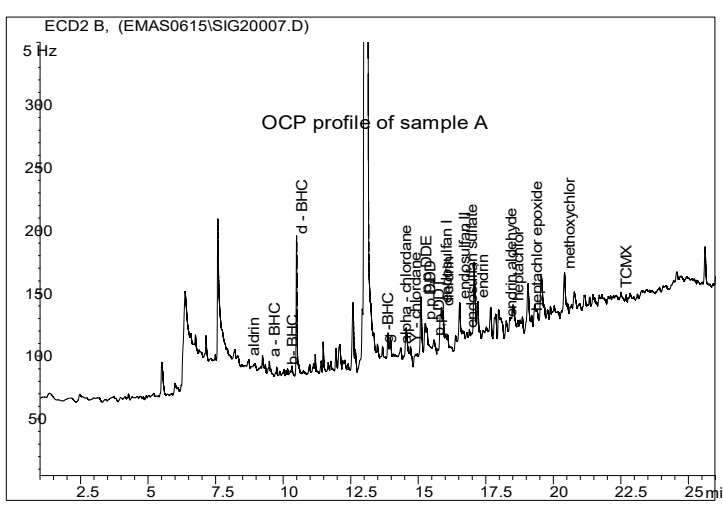

a. Chromatogram profile of $100 \%$ polluted farm soil at 3 months after exposure

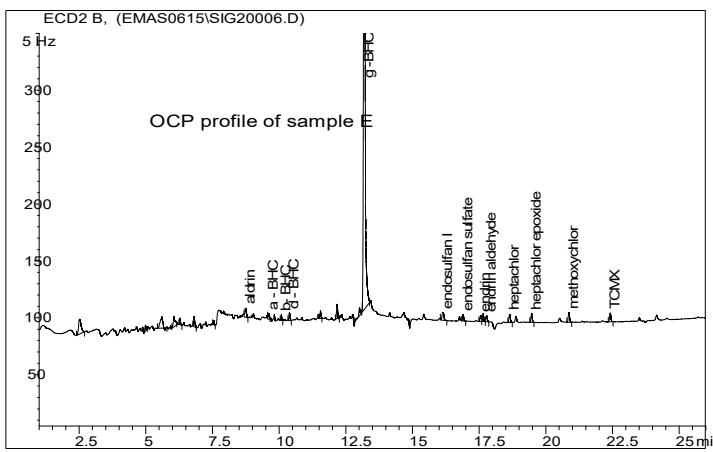

d. Chromatogram profile of polluted farm and control soil mix in the ratio of 5:95 at 3 months after exposure

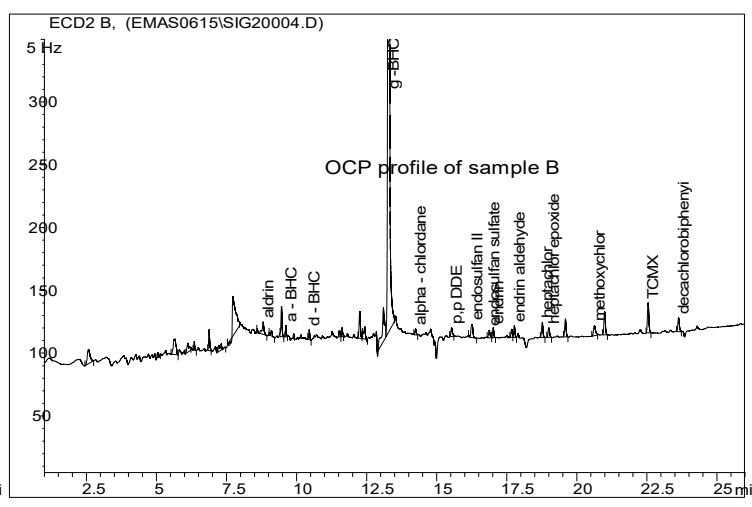

b. Chromatogram profile of polluted farm and control soil mix in the ratio of 75:25 at 3 months after exposure

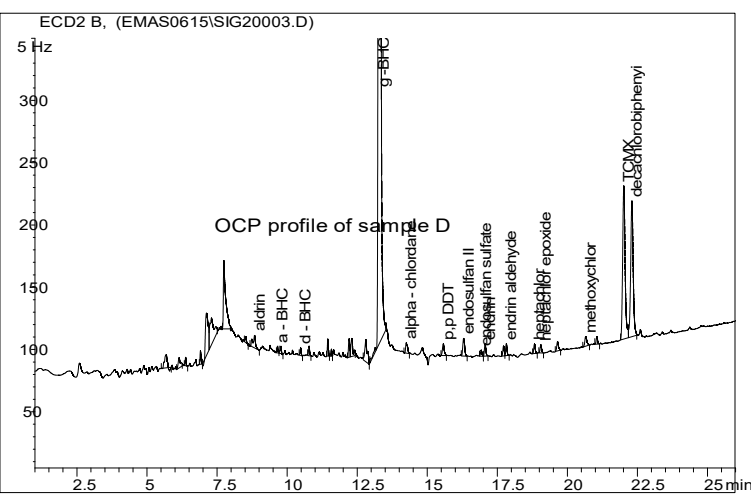

e. Chromatogram profile of polluted farm and control soil mix in the ratio of 75:25 at 3 months after exposure

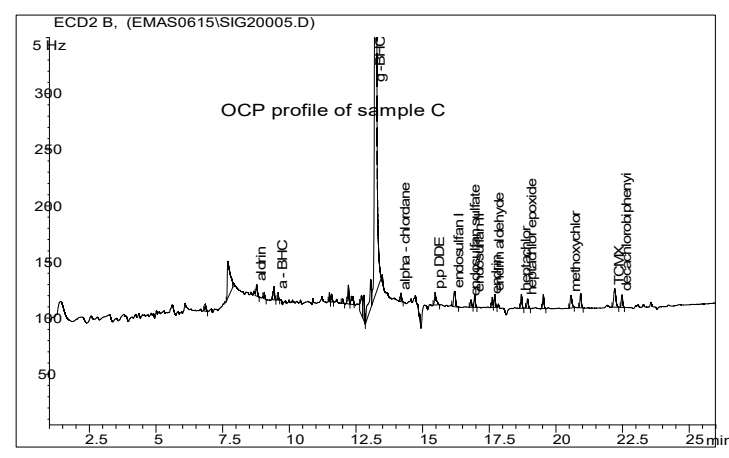

c. Chromatogram profile of $100 \%$ control soil at 3 months after exposure

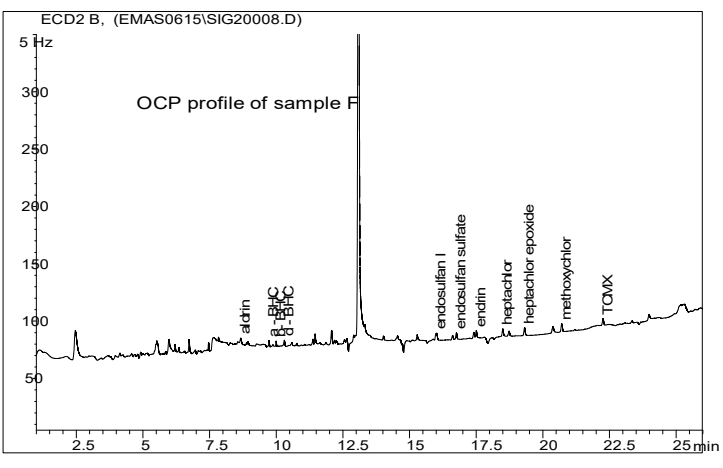

f. Chromatogram profile of polluted farm and control soil mix in the ratio of 1:99 at 3 months after exposure

\section{Figure 3}




\section{Soil pH and Electrical Conductivity}

Figure 4 presents soil $\mathrm{pH}$ values recorded a day before transplanting (1DBT), 1 week after transplanting (1WAT) and 11 weeks after transplanting (11WAT). All soil mixtures were acidic, though a minimal increase in $\mathrm{pH}$ was observed at 1WAT of the test plant and a further increase was observed at the 11WAT in all treatments. The control soil showed the highest $\mathrm{pH}$ increase at 11 WAT (6.23), followed by the soil with least pesticide (1P:99C -5.92). The soil with the highest pesticide showed lowest $\mathrm{pH}(100 \mathrm{P}-4.16)$, showing the high acidic nature of the pesticide impacted soil (Fig. 5). Changes in soil pH have been documented by Marschner (2013) to significantly disturb plant growth and development. This may be the reason why the test plants in pesticide impacted soil, exhibited lower plant heights, peduncle length and number of leaves, compared to the control (Table 2). In present study, a $\mathrm{pH}$ range of 4.0-6.23 was observed, which confirms the acidic nature of the soil. $\mathrm{pH}$ of this range has been reported by Thompson et al. (2001) to impair growth of rice. This is the likely the reason why the control soil flourished better than all treatments (Figure 2).

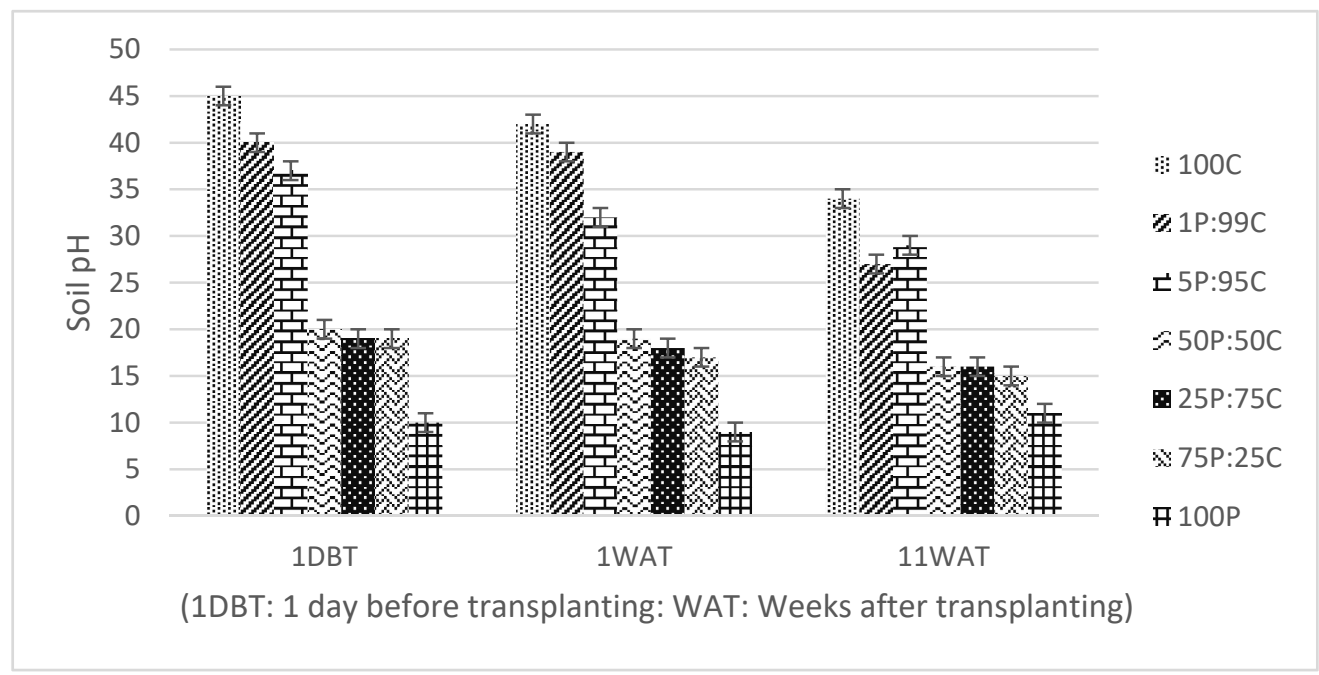

Figure 4. Changes in soil $\mathrm{pH}$ of the experimental treatments with the introduction of $E$. Indica seedlings.

The conductivity of the experimental soils ranged between 9-45 $\mu \mathrm{scm}^{-1}$ (Figure 5). The control soil showed greater conductivity, which reduces with the application of the test plant. This may be linked to the work of Corwin and Yemoto (2017), showing increase in $\mathrm{pH}$ results decrease conductivity. For an acidic soil, the lower the $\mathrm{pH}$, the greater the conductivity (Ikhajiagbe et al., 2019. The treatment with the least pesticide (P1:C99) showed minimum conductivity (40-27 $\left.\mu \mathrm{scm}^{-1}\right)$. This may suggest the reason why the (P1:C99) treatment it have the least pesticide residue after 3 months of the experiment. This assumption agrees with the work of AbdulGhany et al. (2003). 


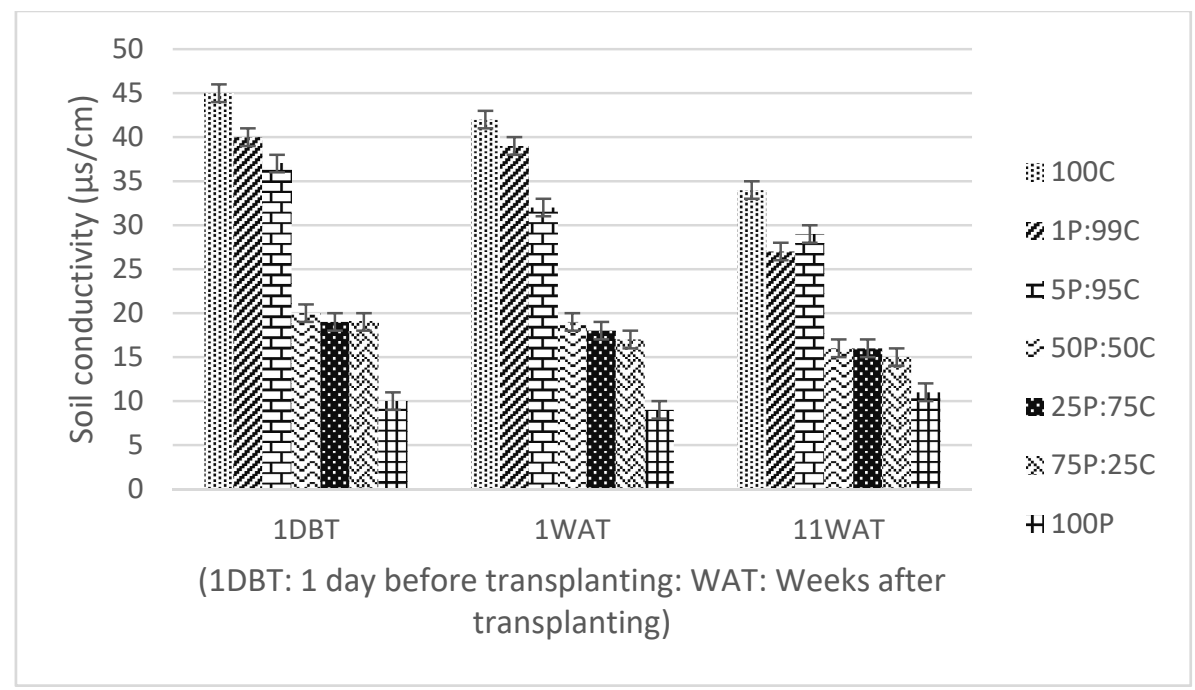

Figure 5. Changes in conductivity of pesticide-contaminated soil after the introduction of $E$. indica seedlings.

\section{Conclusion}

Pesticide impacted soils are more acidic than the control, though the $\mathrm{pH}$ reduces with the introduction of the test seedlings. The conductivity also reduces with increase in soil $\mathrm{pH}$, although minimal conductivity is observed in P1:C99 treatment. The pesticide impacted soil does not show significant morphological response compared to the control. The soil with the least concentration of pesticide in soil showed the highest phytoremediative efficacy. This research suggests that E. indica has potential plant for phytoremediation of organochlorine pesticide polluted soil, though it proved to be concentration-dependent.

\section{Acknowledgements}

The authors acknowledge all advices and collaborations from team members of the Environmental Biotechnology and Sustainability Research Group and the Department of Biological Sciences, Admiralty University of Nigeria.

\section{References}

Abdul-Ghany, O., Sarmamy I and Khidir, S.M. 2003. Effects of some soil treated pesticides on growth characteristics of faba bean \& wheat plants. International Journal of Emerging Technology, Computer and Applied Science 5(1): 7 -20.

Abhilash, P.C., Srivastava, S., Srivastava, P., Singh, B., Jafri, A. and Singh, N. (2011). Influence of rhizospheric microbial inoculation and tolerant plant species on the rhizoremediation of lindane. Environmental Experimental Botany. 74:127-130.

Agbeve, S.K, Carboo, D., Duker-Eshun, G., Afful, S. and Ofosu, P. (2013). Burden of organochlorine pesticide residues in the root of Cryptolepis sanguinolenta, antimalarial plant used in traditional medicine in Ghana. European Chemical Bulletin. 2(11): 936-941. 
Anoliefo, G.O., Ikhajiagbe, B., Okonokhua, B.O., and Diafe, F.V. (2006). Ecotaxonomic distribution of plant species around auto mechanic workshops in Asaba and Benin City: Identification of oil tolerant species. African Journal of Biotechnology. 5(19): 1757-1762.

Anoliefo, G.O., Ikhajiagbe, B., Okonokhua, B.O., Edegbai, B.E., and Obasuyi, O.C. (2008). Metal tolerant species distribution and richness in and around metal based industries: possible candidates for phytoremediation. African Journal of Environmental Science and Technology. 2. (11): 360-370.

Arslan, M., Imran, A., Khan, Q.M. and Afzal, M. (2015). Plant-bacteria partnerships for the remediation of persistent organic pollutants. Environmental Science and Pollution Research. Doi: 10.1007/s11356-015-4935-3.

ASTMD. 2013. Standard Test Method for Determination of Polychlorinated Biphenyls (PCBs) in Waste Materials by Gas Chromatography, ASTM International, West Conshohocken, PA, 1998, www.astm.org.DOI:10.1520/D6160-98.

Barrett, M. (1998). Cloning and heterologous expression of pesticide metabolizing cytochrome P450 genes. Springfield, VA: National Technical Information Service, Fedrip Database.

Becerra-Castro, C., Prieto-Fernández, Á., Kidd, P.S., Weyens, N., Rodríguez-Garrido, B., Touceda-González, M., Acea, M.J. and Vangronsveld, J. (2013). Improving performance of Cytisus striatus on substrates contaminated with hexachlorocyclohexane $(\mathrm{HCH})$ isomers using bacterial inoculants: developing a phytoremediation strategy. Plant Soil. 362:247-260.

Corwin, D. and Yemoto, K. (2017). Salinity: Electrical conductivity and total dissolved solids. Methods of Soil Analysis 2. doi:10.2136/msa2015.0039.

Dewailly, É., Mulvad, G., Pedersen, H.S., Ayotte, P., Demers, A., Weber, J-P. and Hansen, J.C. (1999). Concentration of organochlorines in human brain, liver, and adipose tissue autopsy samples from Greenland. Environmental Health Perspectives. 107:823-828.

Food and Agricultural Organization. (2007). Production year book 2007. 89. Rome. FAO. 325 pp.

Helfrich, L.A., Weigmann, D.L., Hipkins, P. and Stinson, E. (2009). Pesticides and aquatic animals: a guide to reducing impacts on aquatic systems In: Virginia Polytechnic Institute and State University, USA. Available from https://pubs.ext.vt.edu/240/420-013/420013.html.

Ikhajiagbe, B. and Anoliefo, G.O. (2012). Substrate bioaugumentation of spent engine oil polluted soil. Environmental and Earth Sciences Research Journal. 4(1): 60 - 67.

Ikhajiagbe, B., Anoliefo, G.O., Idiagi, O.I. and Omoregbee, O. (2016). Performance of Eleusine indica to abiotic stress occasioned by pollution of the pesticide 2, 2- dichlorovinyl dimethylsulphate. FUW Trends in Science and Technology Journal. 1(2): 399 - 405.

Ikhajiagbe, B., Musa, S.I. and Okeme, J.O. (2019). Effect of changes in soil cation exchange capacity on the reclamation of lead by Eleusine indica (L.) Gaertn. FUDMA Journal of Sciences. 3(4): $176-183$.

Khan, M.U., Sessitsch, A., Harris, M., Fatima, K., Imran, A., Arslan, M., Shabir, G., Khan, Q.M. and Afzal, M. (2014). Cr-resistant rhizo-and endophytic bacteria associated with Prosopis juliflora and their potential as phytoremediation enhancing agents in metal-degraded soils. Frontiers in Plant Science. 5:755.

Lah, K. (2011). Effects of pesticides on human health. In: Toxipedia. Available from http://www.toxipedia.org/display/toxipedia/Effects. Accessed date $28^{\text {th }}$ march, 2020.

Lal, R. and Saxena, D.M. (1982). Accumulation, metabolism, and effects of organochlorine insecticides on microorganisms. Microbiology and Molecular Biology Reviews. 46(1): 95-127.

Laws, E.A. (2000). Aquatic Pollution 3rd ed. John Willey and Sons. 672.

Marschner, H. (1991). Mechanisms of adaptation of plants to acid soils. Plant \& Soil. 134: 1 20. 
McCutcheon, S.C. and Schnoor, J.L. (2003). Phytoremediation: transformation and control of contaminants. New Jersey, NJ, USA: John Wiley \& Sons, Inc.

Miguel, A.S., Ravanel, P. and Raveton, R. (2013). A comparative study on the uptake and translocation of organochlorines by Phragmites australis. Journal of Hazardous Materials. 244 245:60- 69 .

Musa, S.I., Awayewaserere, K.O. and Njoku, K.L. (2019). Effects of dumpsite soil on the leaf structures of Luffa cyclibdrical (Sponge gourd) and Amaranthus viridis (Green Amaranth). Journal of Applied Sciences and Environmental Management. 23(2): 307-311. https://dx.doi.org/10.4314/jasem.v23i2.17

United States Department of Agriculture (USDA, 1998). National Agricultural Statistics Service. Agricultural Statistics Annual. United States Government Printing Office, Washington, DC. 20402-9328

ISBN O-16-036158-3 Obida, M.G., Stephen, S.H., Goni, A.D. and Victor, O.O. (2012). Pesticide residues in Bean samples from Northeastern Nigeria. ARPN Journal of Science and Technology. 2(2): $79-84$.

Ogbeibu, A.E. (2005). Biostatistics: A practical approach to research and data handling. Mindex Publishing Company Limited, Benin City, Bebin. 264p.

Olawale, A.K. and Akintobi, O.A. (2011). Biodegradation of glyphosphate pesticide by bacteria isolated from Agricultural soil. Report and Opinion. 3(1): 124 - 128.

Pope, J.V., Skurky-Thomas, M. and Rosen, C.L. (1994). Toxicity: Organochlorine Pesticides. Medscape Education Emergency Medicine. 2021 accessed.

Sandra, R.R., Mário, S.G., João, R.F., Marli, G., Homero, M.G., Renata, R. and Marcos, V. (2015). Evaluation of Ricinus communis L. for the phytoremediation of polluted soil with organochlorine pesticides. BioMed Research International. p. 8. http://dx.doi.org/10.1155/2015/549863

Sarvajeet, S.G., Naser, A.A., Ritu, G. and Narendra, T. (2016). Abiotic stress signaling in plantsan overview. Wiley wiley-VCH verlag $\mathrm{GmbH}$ and Co. Weinheim, Germany. Pp. 3-22.

Schroll, R., Bierling, B., Cao, G., Dorfler, U., Lahaniati, M., Langenbach, T., Scheunert, I. and Winkler, R. (1994). Uptake pathways of organic chemicals from soil by agricultural plants. Chemosphere. 28:297-303.

Tanvi, S. and Dileep, K. (2017). Phytoremediation of organochlorine pesticides: Review. International Journal of Phytoremediation. DOI:10.1080/15226514.2017.1290579.

Thompson, K., Hodgson, J.G., Grime, J.P. and Burke, M.J. (2001). Plant traits and temporal scale-evidence from a 5 year invasion experiment using native species. Journal of Ecology. 89: 1054 - 1060.

Trapp, S. and Matthies, M. (1997). Generic one-compartment model for uptake of organic chemicals by foliar vegetation. Environmental Science \& Technology. 29:2233-2338.

United Nations Environment Programme (UNEP). 2003. Guidance on the Global Monitoring Plan for Persistent Organic Pollutants, Preliminary Version, United Nations Environment Programme (UNEP), Nairobi, Kenya.

Yanyu, S., Changchun, S., Songbai, J., Junhai, C., Jun, G. and Quandong, Z. (2010). Hydroponic uptake and distribution of nitrobenzene in phragmites australis: potential for phytoremediation. International Journal of Phytoremediation. 12:217-225. 